\title{
Some applications of geochemical and isotopic techniques to hydrogeology of the caves after research in two sites (Nerja Cave-S Spain, and Fourbanne system-French Jura)
}

\author{
Jacques Mudry ${ }^{1}$, Bartolomé Andreo ${ }^{2}$, Arnaud Charmoille ${ }^{1,3}$, Cristina Liñán ${ }^{2,4}$, Francisco Carrasco ${ }^{2}$
}

\begin{abstract}
:
Mudry J., Andreo B., Charmoille A., Liñán C., Carrasco F. 2008. Some applications of geochemical and isotopic techniques to hydrogeology of the caves after research in two sites (Nerja Cave-S Spain, and Fourbanne system-French Jura). International Journal of Speleology, 37 (1), 67-74. Bologna (Italy). ISSN 0392-6672.

Caves constitute privileged sampling spots to investigate the hydrochemical behaviour of infiltration, but the representative nature of samples can limit their reach. Taking this into account many results can be obtained from chemistry of water sampled in the caves. Carbonate tracers enable to reconstruct the 'history' of drip water water, including rainfall and temperatures. Moreover, permanent drip waters prove durability of water stored in the unsaturated zone over the cave, and lags between rain inputs and drip output enable to evaluate transit time through the unsaturated zone. The comparison of input/output concentrations can also contribute to estimate the local water balance of the site.Finally, providing an access to the water table of the saturated zone, caves allow a calculation of mixing rates of infiltration water with water stored in the saturated zone.
\end{abstract}

Keywords: caves, hydrochemistry, isotope, residence time, water balance

Received 27 June 2007; Revised 12 December 2007; Accepted 4 January 2008.

\section{INTRODUCTION}

The karstic cavities have been traditionally studied from a scientific approach because they constitute the only natural way to enter into the karst aquifers, normally in the unsaturated zone. Previous investigations show the importance of unsaturated zone in the functioning of karstic aquifers. Thus, Williams (1983; 2008) and Perrin et al. (2003a) showed the role of the subcutaneous zone and the epikarst in the storage and maintenance of baseflow. Bottrel and Atkinson (1992) demonstrated by tracer test the relationship between residence time and the interconnectivity of the flow path. Tracing investigations done by Bottrell and Atkinson (1992), Smart and Friederich (1986) and Kogovsek (1997) have demonstrated that transit time

1 UMR Chromo-Environnement, UFR Sciences et Techniques, Université de Franche-Comté, 16 route de Gray, 25030

Besançon, France. jacques.mudry@univ-fcomte.fr

2 Departamento de Geología, Facultad de Ciencias, Málaga,

España.andreo@uma.es, fcarrasco@uma.es

3 INERIS - DRS - ESEG, Parc Technologique Alata, BP 2 F-

60550 Verneuil-en-Halatte

4 Fundación Cueva de Nerja, Nerja (Málaga), España. cbaena@ cuevanerja.com between surface and caves can lag for hours in many cases. However this lag time could be months in other cases (Bakalowicz and Jusserand, 1987; Carrasco et al., 2006). Several authors deduced that hydrological functioning at drip water points inside caves depend on the overall volume of rainwater infiltrated in the aquifer (Baker et al., 1997; Liñán et al., 1999). Genty and Deflandre (1998) demonstrated that drip rate is influenced not only by rainfall but also by changes in the atmospheric pressure.

Understanding the functioning of the unsaturated zone of carbonate aquifers is highly interesting because it determines the passage of water towards the aquifer, and it is involved in karstification processes and in the types of water flow that may occur. Moreover, as water flows through this zone towards the inner part of the system, it is mineralised and the input signal is homogenised, i.e. the chemical and isotopic differences of the rain water are reduced. Yonge et al. (1985) showed that this homogenisation could occur in few meters of thickness.

Two types of infiltration can be distinguished in the unsaturated zone of carbonate aquifers (Bakalowicz, 1995; Perrin et al., 2003b): the first of these corresponds to the circulation of water through karst conduits, which ensures the rapid transit of water 
towards deeper zones, with relatively high, but shortlived flow volumes. The second type features the slow circulation of water through the matrix bedrock and fissures, with a small flow volume and a low velocity.

Karst aquifers present an organised structure comprised of different types of drainage (Mangin, 1975; Bakalowicz, 1995; Maloszewski et al., 2002) in which caves may be formed. Such caves can give rise to significant volumes of water flow. The evolution of a karstic structure over time leads to some drains losing their function and to caves being located in the unsaturated zone (Jennings, 1987; White, 1988; Dreybrodt, 1988; Ford and Williams, 1989; 2007). These caves are subjected both two types of infiltration described above and are therefore excellent sites for studying behaviour patterns of the unsaturated zone of carbonate aquifers and the transit time of rain water.

Different methods may be used to study the unsaturated zone of karstic aquifers, one of which is the analysis of the chemical and isotopic composition of water that flows into the cave. The chemical composition and the stable isotopes of water constitute natural tracers which are widely applied in karstic hydrogeology (Bakalowicz, 1979; Mudry, 1981). The chemical and isotopic composition of drip water has been the object of investigations in caves. Thus, for example, Bakalowicz and Jusserand (1987) used this methodology to investigate infiltration into the karstic massif of the Niaux cave (French Pyrenees), Yonge et al. (1985) analysed the stable isotopes of the drip water within numerous caves in USA, Caballero et al. (1996) obtained the first isotopic characterisation of the drip water within the Nerja cave (Spain), Fairchild et al. (2000) studied water chemistry in several European caves.

The aim of this contribution is to show a short descriptive summary on the potentialities of hydrochemical and isotopical tools for hydrogeological investigations in caves, considering the caves as part of karst aquifers where they are located and particularly on the unsaturated zone of these. Examples from the hydrogeological literature are cited in this work but two main examples of karst systems are considered as pilot sites: Fourbanne in the Jura mountains and Nerja Cave in the Alpine mountains of Betic Cordillera

\section{HYDROCHEMICAL MONITORING IN CAVES: ADVANTAGES AND PROBLEMS}

Caves are privileged places of carbonate dissolution and they constitute observation spots for all the flow components of karst groundwater, due to their property of accessible voids in the massif. As voids of the unsaturated zone, caves enable to sample both more or less concentrated drip water flows, and conduits at the surface of the saturated zone. Therefore, depending of their location they permit to investigate the behaviour of the whole system. In any case, water discharge should be measured in gauging stations such as a rain gauge for low drip water flow or weir-type for higher flow rate (Groves, 2007).
In the dry caves or dry parts of caves, devices can be easily installed, to monitor $\mathrm{pH}$, electrical conductivity, redox potential, dissolved oxygen or $\mathrm{CO}_{2}$ of drip water (Fig. 1). Continuous records of these parameters are suitable for hydrogeological research in caves, particularly during high water conditions (Jeannin et al., 2007). Monitoring drip water with hourly interval during several floods is also highly desirable. Sometimes, due to the frequentation of caves, the recording devices should be protected from vandalism. Buffered temperature variations facilitate quality measurements, but the high air moisture induces to shelter electronic acquisitors in watertight boxes.

More delicate are measurements at the surface of the saturated zone, because of the head amplitude, which often requires to place the recording machine out of reach of the highest flood level, which necessitates installation of electric wires between the probes and the acquisitors.

A problem of using caves as observation places is the difficulty of progression in the galleries or shafts, every hydrogeologist not being necessarily a perfect speleologist. Another problem is to access measurement or sampling sites during high water periods, when some galleries can be temporarily flooded, limiting thus access. In any case, conservation and calibration of the probes must been done for monitoring in caves.

\section{CARBONATE CHEMISTRY}

A cave is a special interface between seepage water, aired gallery and fractured limestone. In the general case of gravitational or classical karsts, in which $\mathrm{CO}_{2}$ originates mainly from pedogenic processes, water is hydrating (1) and then ionizing (2 \& 3) $\mathrm{CO}_{2}$ within the humic topsoil (Dreybrodt, 1988): $\mathrm{CO}_{2}+n \mathrm{H}_{2} \mathrm{O} \Leftrightarrow\left(\mathrm{CO}_{2}, n \mathrm{H}_{2} \mathrm{O}\right)$ $\left(\mathrm{CO}_{2}, n \mathrm{H}_{2} \mathrm{O}\right)+p \mathrm{H}_{2} \mathrm{O} \Leftrightarrow \mathrm{HCO}_{3}^{-}+\mathrm{H}_{3} \mathrm{O}^{+}+(\mathrm{n}-\mathrm{p}-1) \mathrm{H}_{2} \mathrm{O}(2)$ $\mathrm{HCO}_{3}{ }^{-}+\mathrm{H}_{2} \mathrm{O} \Leftrightarrow \mathrm{CO}_{3}^{2-}+\mathrm{H}_{3} \mathrm{O}^{+}$ $\mathrm{CaCO}_{3} \Leftrightarrow \mathrm{Ca}^{2+}+\mathrm{CO}_{3}^{2-}$

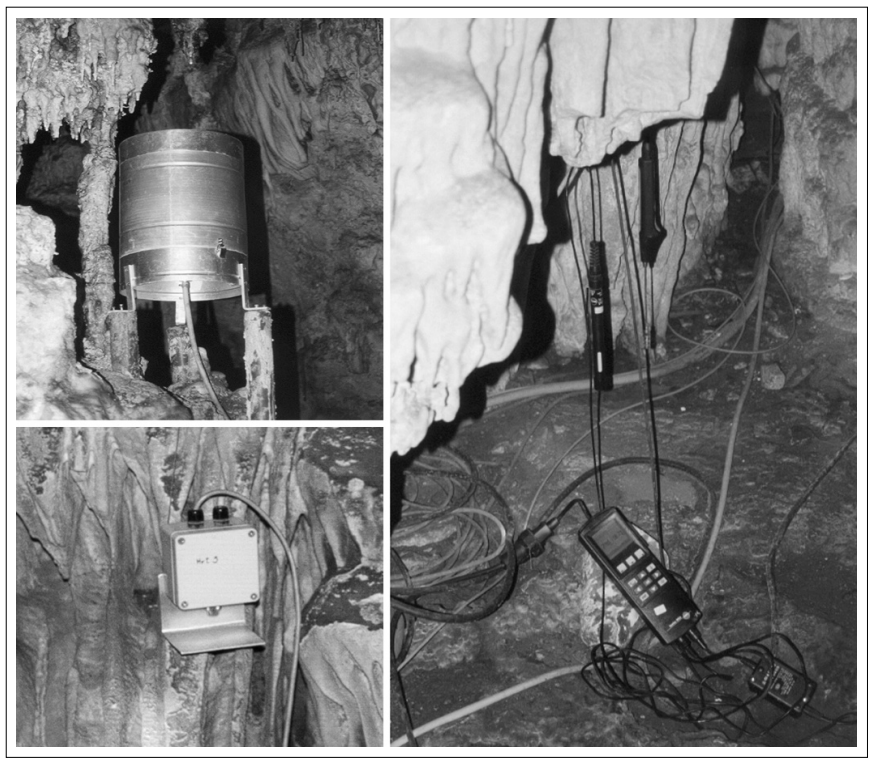

Fig. 1. Monitoring drip water in Nerja Cave. 
As soon as seepage water reaches the carbonate medium, this carbonic acid dissolves carbonate minerals (e.g.: calcite), displacing to the right the following global equation: $\mathrm{CaCO}_{3}+\mathrm{CO}_{2}+\mathrm{H}_{2} \mathrm{O} \Leftrightarrow \mathrm{Ca}^{2+}+2 \mathrm{HCO}_{3}^{-}$

Within the fractured unsaturated medium, water is in thermodynamical equilibrium with the soil atmosphere, i.e. with a $\mathrm{CO}_{2}$-rich gas phase (order of magnitude: $10^{-2} \mathrm{~atm}$ ). A cave is a medium generally open to the outer $\mathrm{CO}_{2}$-poor atmosphere (order of magnitude: $\left.10^{-4} \mathrm{~atm}\right)$. Due to this high contrast, water reaching the cave atmosphere has a degassing tendency, displacing to the left the global equation, precipitating thus solid carbonate that constitutes speleothems or rimstone pools. Prior calcite precipitation can occur up-flow of the point where drip water is sampled or is precipitating speleothem calcite. Drip water $\mathrm{Ca}$ concentration is important for calcite precipitation but the influence of changes in $\mathrm{P}_{\mathrm{CO} 2}$ in the cave and their effect on carbonate saturation must also be taken into account. Prior calcite precipitation will be enhanced by seasonal falls in $\mathrm{CO}_{2}$ in the cave atmosphere and seasonally low flows (Fairchild et al., 2006; Fairchild $\&$ McMillan, 2007). The consequence of degassing and prior calcite precipitation is an increase in $\mathrm{Mg}$ and Sr of dripwater and consequently in the speleothem. Thus the simultaneous enrichment in both $\mathrm{Sr}$ and $\mathrm{Mg}$ in speleothems is a marker of this geochemical process which could be due to climatic reasons, mainly arid periods (Fairchild et al., 2006; McMillan et al., 2005).

From a hydrochemical point of view some investigations have been performed of the chemical composition of water in the soil (Smart and Friederich, 1986) and in the unsaturated zone (Bakalowicz, 1995) which depends on the type of flow (preferential flow or matrix flow) that takes place in karst systems. Tooth and Fairchild (2003) deduced different chemical processes (prior calcite precipitation, dilution, piston flow) controlling the chemistry of drip water inside a cave as response to differing hydrological responses to rainfall. Percolation water into a cave is a diphasic flow of water and $\mathrm{CO}_{2}$ (Atkinson 1977; Bakalowicz, 1979); the water is submitted to evapotranspiration and to a geochemical evolution depending on the soil and the unsaturated zone and on the transit time. Additional research should be developed in different geological and climatological contexts in order to understand the hydrochemical variations in the unsaturated zone of karst aquifers.

\section{RESIDENCE TIME THROUGH THE UNSATURATED ZONE}

The water flow within a cavity can show a wide range of variation, for example between $\mathrm{cm}^{3} /$ minute and $\mathrm{m}^{3} /$ second orders of magnitude. The temporal evolution of the water flow within the cave depends mainly on the rainfall which is the original input, both as surface precipitation or contribution to runoff of sinking stream into the karst system. In any case, the entrance of water into the cavity plays a major role in environmental parameters of the caves, such as the humidity or the temperature. The simple comparison of entrance (input) and flow rate in the cave (output) permits a first estimation on the transit time. This data can be checked by correlatory and spectral analysis between rainfall and flow rate. However, the hydrodynamic methods inform only on the pressure (or energy) transfer, but not on the mass transfer.

The tracing works of Bottrell and Atkinson (1992), Smart and Friederich (1986) and Kogovsek (1997) all have shown fast transit times with the fastest flows from the surface to caves being hours or less in many cases. On the other hand the lag can be several months long, as Bakalowicz and Jusserand (1987) demonstrate investigating the chemical signal reaching a cave. These authors prove that mean transit time between the input in the surface and output into Niaux cave (Ariège, France) is about 4.5 months as average values.

The unsaturated zone of karst is not only a transit (slow and rapid) place for infiltration. It has also a storage function, due to its porosity, thickness and low permeability, particularly in the epikarst. An evidence of this storage role is observed in caves, where permanent drips exist below stalactites, even during periods devoid of precipitations in the Mediterranean countries.

An example is the Nerja Cave system (Carrasco et al., 2006), where both the rainfall and drip water have been monitored (Figure 1) during the last decade. Figure 2 shows flow of ${ }^{18} \mathrm{O}$ through the unsaturated zone of Nerja cave aquifer. The input flow was calculated from the effective rainfall (Thornthwaite's method, daily, with a $25 \mathrm{~mm}$ soil reserve), multiplied by $\delta^{18} \mathrm{O}$. In general, the winter rainfall episodes are the ones that produce recharge, and so the isotopic inputs to the unsaturated zone are between October and February, together with those that occasionally occur in spring (April and May). Figure 2 represents the ${ }^{18} \mathrm{O}$ fluxes of the input, gathered by rain periods (assigning the obtained sum to the centre of gravity of the period) in order to obtain the time distribution of the major recharge episodes of the aquifer. As a general case, we observe the existence of an input flux to the aquifer, during the months of November and December.

The output flow of ${ }^{18} \mathrm{O}$ into the cavity was determined by multiplying the drip water flow by its $\delta^{18} \mathrm{O}$ value. Maximum values are obtained in summer and autumn (August and September), and occasionally in other periods (December - March) associated with significant rainfall episodes (e.g. end of 1996 and early 1997). The ${ }^{18} \mathrm{O}$ input/output ratio (Fig. 2) for rain water and drip water reveals the existence of a seasonal lag of about 8 months between the input of rainfall and the output of seepage within the cave. This lag, observed for a $30 \mathrm{~m}$ flow through the unsaturated zone, implies low moisture content in the limestone matrix, according to the piston flow model applicable to this medium. Nevertheless, when an important recharge episode occurs (such as in early 1997), the drip water response is faster, the lag never is shorter than 1 to 3 months (Fig. 2). 
There are other examples in the literature concerning stable isotopes where the signal may become homogenised within $10 \mathrm{~m}$ of the surface (Yonge et al., 1985). These results give credit to the perpetuity of water storage (or slow transit) within this zone, which does not imply that the whole saturated zone is filled by water, but that a discontinuous groundwater persists in this medium.

$\delta^{18} \mathrm{O}$ of drip water depends, among other factors, on the vapour source and on the altitude of recharge, which are related to the temperature. Thus, speleothems forming dripwater have been considered historically as an indicator of paleotemperatures. However, when the results of this proxy can be calibrated in the instrumental period, there are discrepancies with other paleoclimatic indicators, because there are other factors such as the rainfall amount effect. Speleothems depend on the availability of dripwater which is related to the quantity of rainwater infiltrating into the karst aquifer on different time scales (Fairchild et al., 2006; Carrasco et al., 2006). Spatial variations in soil structure can potentially lead to spatial differences in $\delta^{18} \mathrm{O}$ in contemporaneously deposited stalagmites (Fairchild et al., 2006). Similarly $\delta^{13} \mathrm{C}$ has been historically interpreted in terms of vegetation type but it depends also on the hydrological conditions (Fairchild et al., 2006).

Calculations of $\mathrm{P}_{\mathrm{CO} 2}-\mathrm{CO}_{2}$ (partial pressure of $\mathrm{CO}_{2}$ of a fictitious gaseous phase in equilibrium with the solution) and $\delta^{13} \mathrm{C}$ provides indication about the storage place of water. Water stored in the unsaturated zone is likely in contact with a gas phase containing elevated concentration of $\mathrm{CO}_{2}$. Thus, carbonate dissolution evolves under open system conditions resulting in a higher final $\mathrm{P}_{\mathrm{CO} 2}$ and more negative $\delta^{13} \mathrm{C}$.
In contrast, water from the saturated zone may have little contact with the gas phase, the $\mathrm{P}_{\mathrm{CO} 2}$ is lower and the ${ }^{13} \mathrm{C}$ values are more enriched by a long interaction time with the carbonate rocks. The Total Organic Carbon (TOC) shows high concentration values when transit time is short, whilst TOC is low if water has a long residence time, sufficient to mineralise dissolved organic carbon. Combining TOC and $\delta^{13} \mathrm{C}$, together with chemical components (as $\mathrm{Mg}$ coming from large residence time predominantly in the saturated zone, and $\mathrm{Cl}^{-}$and $\mathrm{NO}_{3}^{-}$coming from the unsaturated zone), the saturated and unsaturated components can be demonstrated and quantified, using the response at the outlet, even after transit through the saturated zone. For example, $\delta^{13} \mathrm{C}$ measurements have enabled to evaluate this contribution up to $25 \%$ at the Fontaine de Vaucluse spring (Emblanch et al., 2003).

The residence time through the unsaturated zone deduced from hydrochemical and isotopic data is a key factor to validate contamination vulnerability maps and to delineate cave protection schemes (Zwahlen, 2004). Thus, the use of environmental tracing (chemical and isotopic) is interesting to classify karst systems according to their vulnerability to the contamination.

\section{GLOBAL ESTIMATION OF THE WATER BALANCE}

Due to the access provided to the shallow part of the karst massif, caves enable to sample seepage water both in hierarchized flow areas (unsaturated conduits) and in thinly fissured blocks. This situation makes it possible to compute a local chemical hydrologic balance for the recharge area

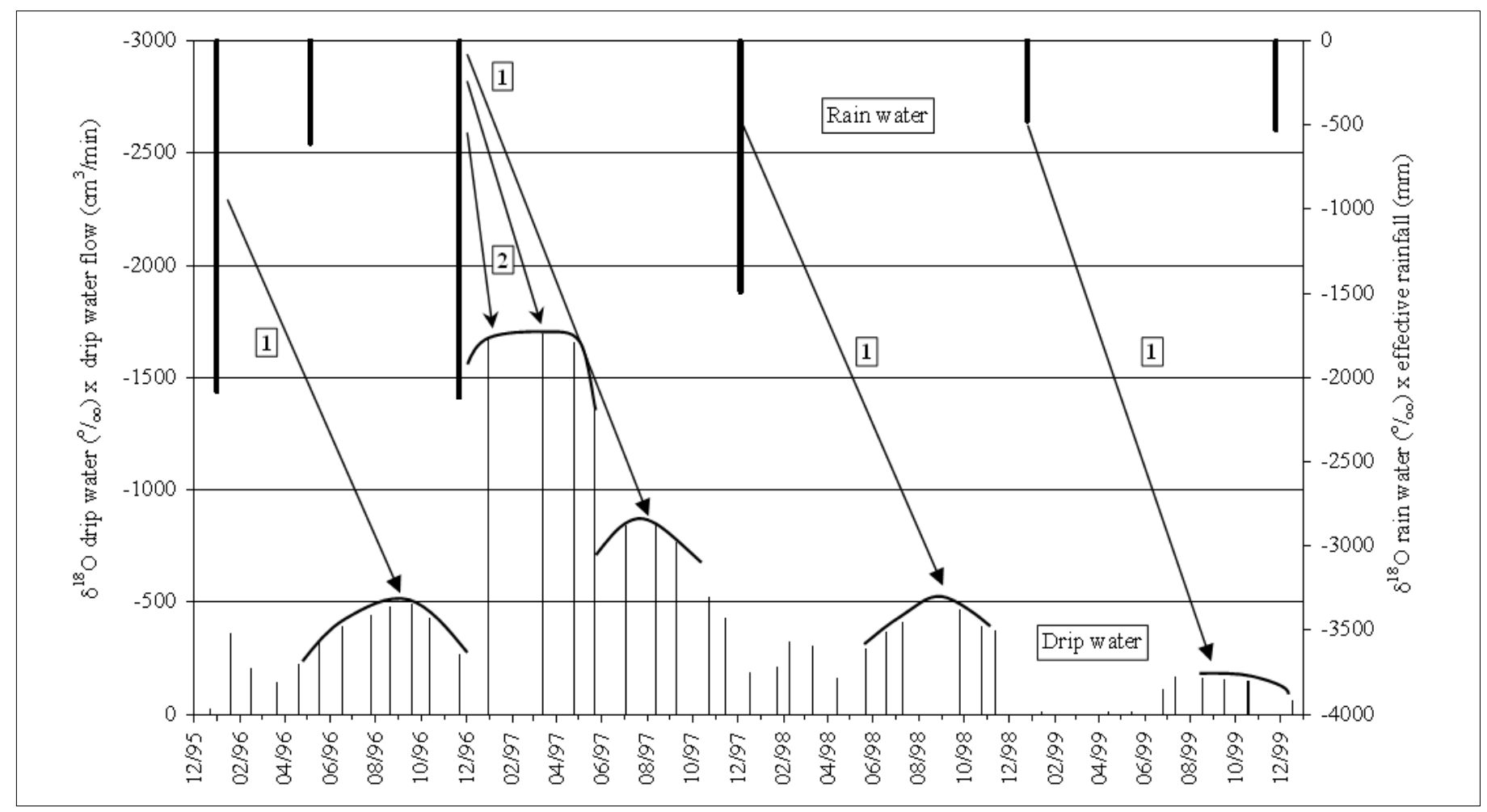

Fig. 2. Lag in the breakthrough of infiltration, Nerja Cave, Andalusia, South Spain. 1: slow flow (8 months), 2: rapid flow (2 months). (after Carrasco et al 2006). See comments in the text. 
of each sampling site of water. Considering that rainwater impregnates soil and epikarst, where evaporation operates, the concentration ratio of a natural tracer, allows a direct calculation of effective rainfall, without formulating assumptions about soil moisture and maximum reserve (field capacity).

This method requires, to be reliable, to select conservative tracers (Perrin et al., 2003b; Jeannin et al., 2007) such as halides $\left(\mathrm{Cl}^{-}, \mathrm{Br}^{-}, \mathrm{I}^{-}\right)$or possibly alkali metals $\left(\mathrm{Li}^{+}, \mathrm{Na}^{+}, \mathrm{K}^{+}\right)$which are only provided by rainwater (nor geogenic, nor anthropogenic). Their meteoric concentration (which origin can be exclusively natural, or introduced in the atmosphere by remote air pollution), must be weighted by rainvalues of the different shower episodes. The output is the dripwater concentration, which must be weighted by the discharge of the sampling spot, which requires subsequently drip water flow measurements. The principle of this computation is the mass conservation equation:

$\mathrm{C}_{\mathrm{r}} * \mathrm{R}=\mathrm{C}_{\mathrm{d}} * \mathrm{ER}$

$\mathrm{C}_{\mathrm{r}} \& \mathrm{C}_{\mathrm{d}}$ : concentrations in rainwater $\&$ in dripwater

$\mathrm{R} \& \mathrm{ER}$ : rain value \& effective rainfall (in the same unit, e.g. $\mathrm{mm}$ )

This mass conservation of an environmental tracer enables to evaluate, in a global way, the recharge coefficient $\left(R_{c}\right)$ and then the effective rainfall $(E R)$ and actual evaporation $\left(E_{a}\right)$ for each single component of infiltration:

$$
\begin{aligned}
& \mathrm{R}_{\mathrm{c}}=\mathrm{ER} / \mathrm{R}=\mathrm{C}_{\mathrm{r}} / \mathrm{C}_{\mathrm{d}} \\
& \mathrm{ER}=\mathrm{R} * \mathrm{C}_{\mathrm{r}} / \mathrm{C}_{\mathrm{d}} \\
& \mathrm{E}_{\mathrm{a}}=\mathrm{R} *\left(1-\mathrm{C}_{\mathrm{r}} / \mathrm{C}_{\mathrm{d}}\right)
\end{aligned}
$$

As an example, data from the Nerja cave (Andalusia, Spain, after Liñán et al., 1999) has been considered. Table 1 gives three calculations of the mean chloride concentrations in rainwater and dripwater, based on processing of:

- $\quad$ raw data $(\Sigma$ conc / $\mathrm{n})$,

- $\quad$ weighted synchronic data $\left(\Sigma\left[\operatorname{conc}^{*} \mathrm{R}\right] / \Sigma[\mathrm{R}]\right.$ for rainwater or $\Sigma$ [conc * D] / $\Sigma$ [D] for dripwater), weighted postponed data, shifted forward between rainfalls and drip discharge, to take into account the average 8 month transit time of infiltration water through the carbonate (Carrasco et al., 2006).

The result is that about $1 / 3$ of the $490 \mathrm{~mm}$ mean yearly rainfall infiltrates into the carbonate medium, constituting a good reserve.
Using the input / output concentrations of environmental isotopes is not so easy in caves. Despite the fact that they are subjected to tracing by evaporation, two schematic situations can be observed:

- evaporation concentrates strongly heavy isotopic varieties $\left({ }^{2} \mathrm{H}\right.$ and $\left.{ }^{18} \mathrm{O}\right)$, but do not evaporate the whole soil solution. In this situation, which can be observed in temperate or equatorial regions, samplings at the dripping spots of the cave can be performed, and the isotope concentration can be used as well as conservative salts to compute the local hydrogeologic balance ;

- evaporation exhausts the whole soil solution, and therefore its isotope content. This situation, that can be observed in Mediterranean, semi-arid and arid conditions, prohibits the use of this method for balance calculations, the uppermost concentrated waters being eliminated, and therefore effective rainfall will be overestimated.

\section{PISTON AND MIXING FLOWS}

The difference of response between drainage system and fine fissures karst media can be deduced from the shape of the chemograph of drip water point (Shuster and White, 1971). The organization and the effectiveness of the karst drainage is displayed by sharp peaks, it is able to transmit the infiltration component to the spring during flood period. Conversely, a flat chemograph is commonly interpreted as indicative of low degree of karstification, unable to transfer an input signal to the outlet. Such a system is a good mixer, consisting of a regularly distributed network of fractures with absence of karst drains. However this is a simplistic interpretation since spring variability may be due to variability in recharge, in storage or in flow (Smart and Friederich, 1986). Each of these affects hydrograph shape. Thus a flat chemograph may indicate a high fraction of percolation rather than sinking stream recharge (Worthington et al., 1992).

The frequency distribution (Bakalowicz, 1977) displays similar information. Symmetrical curves

\begin{tabular}{|c|c|c|c|}
\hline & $\begin{array}{l}\text { Mean } \\
\text { concentration } \\
(\text { raw })\end{array}$ & $\begin{array}{c}\text { Mean concentration (weighted by } \\
\text { rain value / discharge) } \\
(\mathrm{mg} / \mathrm{L})\end{array}$ & $\begin{array}{c}\text { Mean concentration (weighted and } \\
\text { shifted } 8 \text { months forward) } \\
(\mathrm{mg} / \mathrm{L})\end{array}$ \\
\hline $\mathrm{C}_{\mathrm{r}}: \mathrm{Cl}^{-}$in rainfalls $(\mathrm{mg} / \mathrm{L})$ & 8.93 & 7.85 & 7.97 \\
\hline $\mathrm{C}_{\mathrm{d}}: \mathrm{Cl}^{-}$in dripwater $(\mathrm{mg} / \mathrm{L})$ & 25.50 & 21.05 & 18.85 \\
\hline
\end{tabular}
with a unique high mode and a small range of values indicates that water drains a lowly karstified

\begin{tabular}{|c|c|c|c|}
\cline { 2 - 4 } \multicolumn{1}{c|}{} & $($ raw $)$ & $\begin{array}{c}\text { (weighted by } \\
\text { rain value / discharge) }\end{array}$ & $\begin{array}{c}\text { (weighted and shifted 8 months } \\
\text { forward) }\end{array}$ \\
\hline$R_{c}=C_{r} / C_{d}$ & 0.35 & 0.37 & 0.42 \\
\hline$E R=R^{*} R_{c}$ & $171 \mathrm{~mm}$ & $183 \mathrm{~mm}$ & $207 \mathrm{~mm}$ \\
\hline$E_{a}=R^{*}\left(1-R_{c}\right)$ & $318 \mathrm{~mm}$ & $307 \mathrm{~mm}$ & $282 \mathrm{~mm}$ \\
\hline
\end{tabular}

Tab. 1. Calculations of the mean chloride concentrations in rainwater and dripwater samples collected in Nerja Cave (after Liñán et al 1999). 
or fissured aquifer, with high mixing capacity. Conversely, curves with several peaks reaching lower frequencies, several modes and large range of variation indicates that karst conduits exist which enable different water types to arrive to the drip water point.

Perrin et al. (2003a, b) and Jeannin et al. (2007) proposed a conceptual model of flow and storage in the unsaturated zone of karst systems depending on the hydrodynamic conditions, after experiences in the Milandre cave site (Switzerland). During low water conditions, the system is fed by water coming from the epikarst and the chemistry of water is invariant. When rain starts, soil water is pushed down to the epikarst and the water stored in this is pushed down to the system; consequently the discharge can increase but the chemistry does not vary so much. If the rain continues, the soil will be saturated and water infiltrated enters directly in the main karstic network, provoking flood conditions and changes in chemical and isotopic composition (normally dilution of water previously stored in the system). In this model, the soil and epikarst storages play a more relevant role than water storage in phreatic system.

Some caves permit to observe water flows in conduits located at the surface of the saturated zone. They can be used to evaluate the role of the saturated zone, and piston-flow or mixing behaviours can then be interpreted. A case example is the Fourbanne karst system, located in the Doubs valley (Jura mountains, Eastern France), which is a mixed autogenic-allogenic system. Part of the infiltration is diffuse on the limestone outcrops, and part originates in swallow holes (Charmoille, 2005).

A main conduit is located at the surface of the saturated zone, which outlet is a spring. The experiment (Fig. 3) consisted in following water from the input place (Verne swallow hole), to the entrance of the saturated zone (Fontenotte cave), and finally to the main outlet (Fourbanne spring). Its originality consisted in analysing the same water volume, traced by uranin at the upstream swallow hole. During a flood (Figs. 4 and 5), magnesium, and nitrate concentrations, representative of the residence time of water, show similar values at Verne and Fontenotte, demonstrating the short residence times sampled in this conduit of the unsaturated zone, and increase $\left(\mathrm{Mg}^{2+}\right)$ and decrease $\left(\mathrm{NO}_{3}{ }^{-}\right)$at the outlet, demonstrating a mixture of this rapid component with $\mathrm{Mg}$-rich and $\mathrm{NO}_{3}$-poor water (out of reach of fertilizer pollution) with a larger residence time, acquired through the saturated reserves. This result highlights the proceeding of two successive flow types: piston flow in the infiltration zone, and then dispersive flow mixing through the saturated zone.

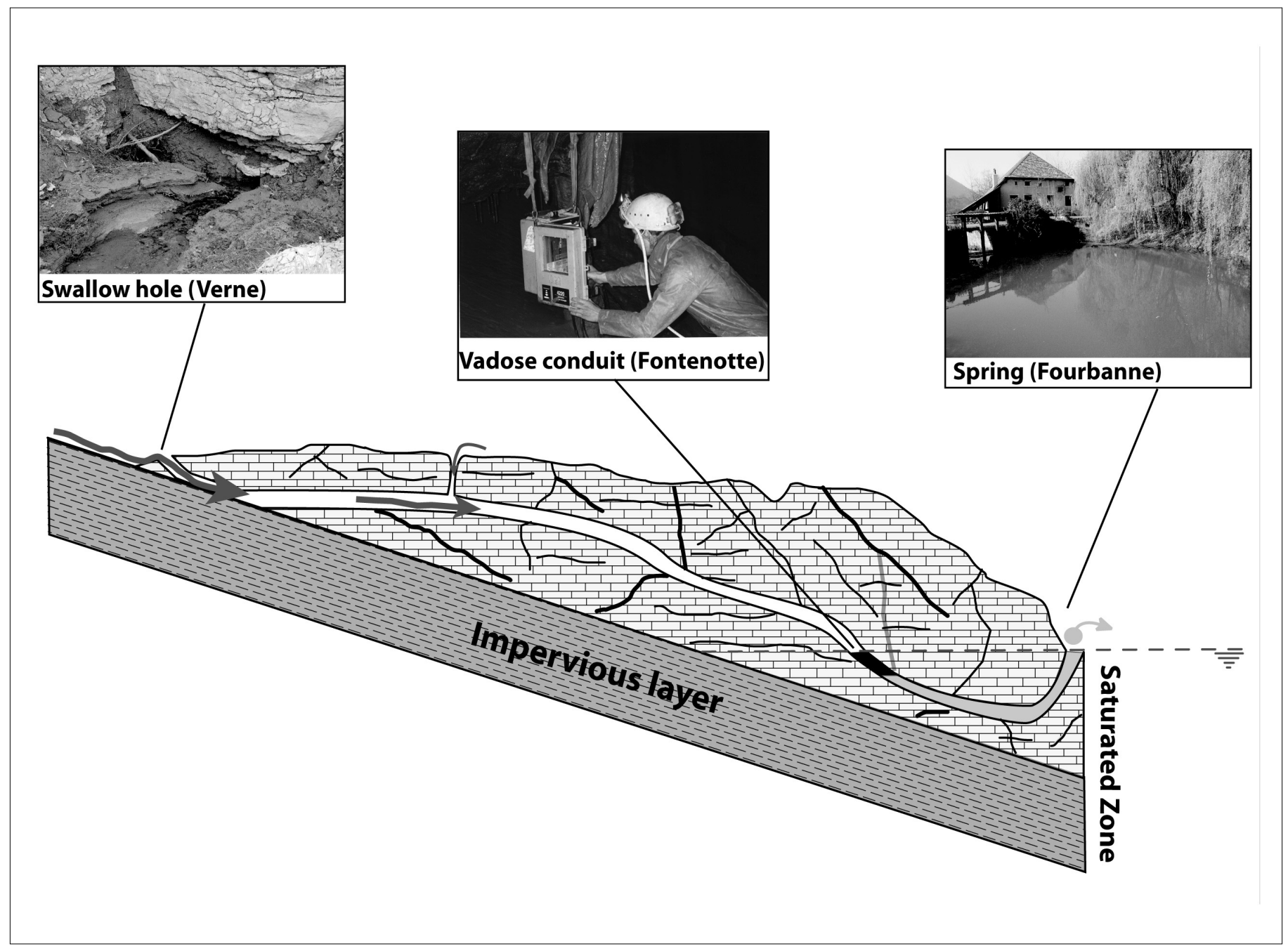

Fig. 3. Three monitoring spots in the Fourbanne karst hydrosystem. 1: swallow hole (Verne), 2 vadose conduits up to the saturated zone (Fontenotte cave), 3: Outlet (Fourbanne spring). (Charmoille, 2005). 


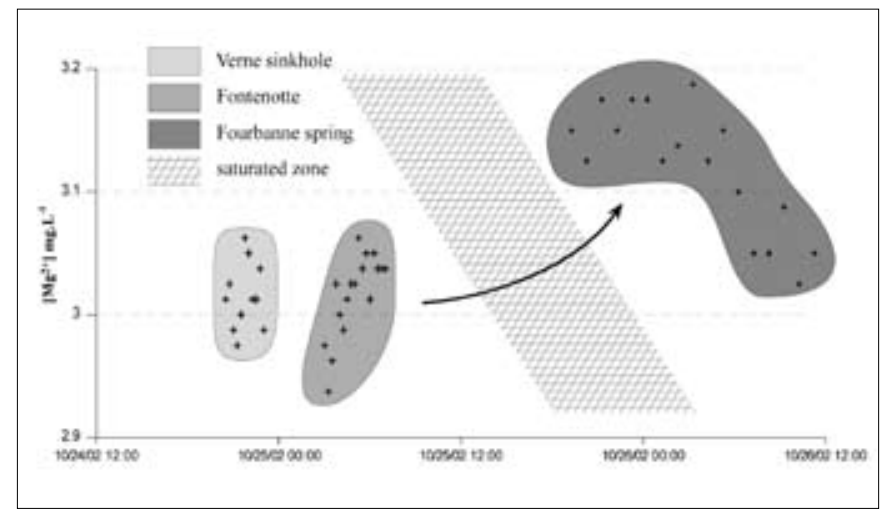

Fig. 4. Magnesium concentration of the same water body, traced by uranin. (Charmoille, 2005).

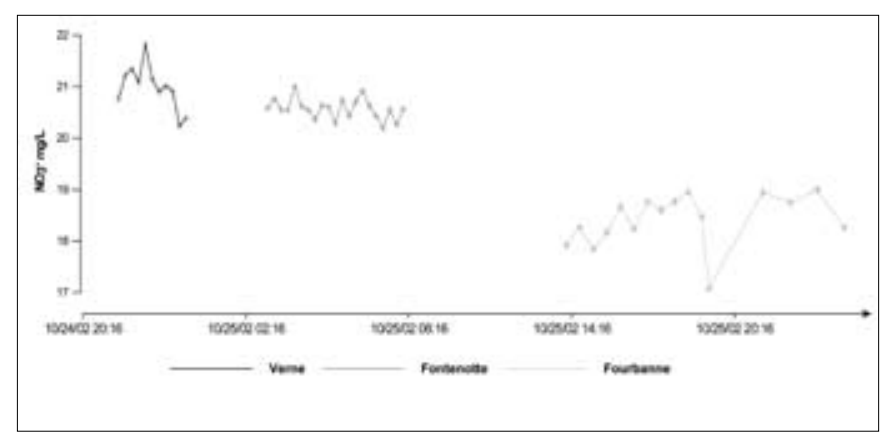

Fig. 5.Nitrate concentration of the same water body, traced by uranin. (Charmoille, 2005).

\section{CONCLUDING REMARKS}

The karst medium contains discontinuous groundwater bodies, ranging from fissured quasihomogeneous aquifers to highly karstified ones, according to their geological history. Because of their existence due to karstification processes, inducing their (past or present) draining role in the massif, caves are priviledged accessible natural structures which enable observation, sampling and monitoring of precipitated carbonates, water and gas. As response to contrasted lithology, structural and genetic originality of karst aquifers and caves inside them, sufficiently contrasted hydrochemical and isotopic responses exist at the drip water points. This permits to assign an origin to the different flows: transmissive conduits or low permeability blocks, shallow or deep storage, point or diffuse recharge.

Water sampling and monitoring contribute to the knowledge of mixing processes of karstic and nonkarstic components near the saturated zone. But their main goals deal with infiltration processes in the vadose zone, highlighting heterogeneity in the quality of water input, revealing heterogeneity of residence times, of water balance, or of contamination status. Caves could be used to investigate these heterogeneities and to assess and to validate vulnerability mapping, by means of hydrochemical and isotopic tools.

Gas sampling, coupled with water sampling, are relevant to study the carbon cycle, crucial in the karstification processes: $\mathrm{CO}_{2}$ distribution and isotopic composition, natural $v$ s anthropic origin.

\section{ACKNOWLEDGEMENTS}

This work is a contribution to the projects IGCP 513 of UNESCO, CGL2005-05427 of DGICYT (Spanish Ministry Education and Science) and P06-RNM02161 of Andalusian Government, co-authorship by members of Research Group RNM-308 of Andalusian Government (B.A., C.L. and F.C.). Criticisms from Andrea Borsato and Steve Worthington contributed to improve the original version of this manuscript.

\section{REFERENCES}

Atkinson T.C., 1977 - Carbon dioxide in the atmosphere of the unsaturated zone: an important control of groundwater hardness in limestones. Journal of Hydrology, 35: 111123.

Bakalowicz M., 1977 - Étude du degré d'organisation des écoulements souterrains dans les aquifères carbonatés par une méthode hydrogéochimique nouvelle. C.R. Acad. Sci. Paris, série D, 284: 2463-2466.

Bakalowicz M., 1979 - Contribution de la géochimie des eaux à la connaissance de l'aquifère karstique et de la karstification. Thèse Doct. Sci. Nat, Paris 6, Géol. Dyn. \& Lab. Sout. CNRS, $269 p$.

Bakalowicz M., 1995 - La zone d'infiltration des aquifères karstiques. Méthodes d'étude. Structure et fonctionnement. Hydrogéologie, 4: 3-21.

Bakalowicz M. \& Jusserand C., 1987 - Etude de l'infiltration en milieu karstique par les méthodes géochimiques et isotopiques. Cas de la Grotte de Niaux (Ariège, France). Bull. Centre d'Hydrogéologie de Neuchâtel, 7: 265-283.

Baker A., Barnes W.L. \& Smart P.L., 1997 - Variations in the discharge and organic matter content of stalagmite drip waters in Lower Cave, Bristol. Hydrological Processes, 11:541-555.

Bottrel S.H. \& Atkinson T.C., 1992 - Tracer study of flow and storage in the unsaturated zone of a karstic limestone aquifer. In: Hötzl H. \& Werner A. (eds.), Tracer Hydrology, Balkema Rotterdam, 207-211.

Caballero E., Jiménez de Cisneros C. \& Reyes E., 1996 A stable isotope study of cave seepage waters. Applied Geochemistry, 11: 583-587.

Carrasco F., Andreo B., Liñán C. \& MudryJ., 2006-Contribution of stable isotopes to understanding the unsaturated zone of a carbonate aquifer (Nerja Cave, southern Spain). Comptes Rendus Geoscience, 338: 1203-1212.

Charmoille A., 2005 - Traçage hydrochimique des interactions hydrauliques et mécaniques entre les volumes perméables et peu perméables au sein des aquifères fracturés carbonatés. Ph D, University of Franche-Comté, Besançon (French). http:/ / tel.archives-ouvertes.fr/ index.php?halsid=82 4ffb077cc3dd33ab06ccacffe 723c\&view_this_doc=tel00011213\&version $=1$

Dreybrodt W., 1988 - Processes in karst systems. Springer-Verlag, $288 \mathrm{p}$.

Emblanch C., Zuppi G.M., Mudry J., Blavoux B. \& Batiot C., $2003-{ }^{13} \mathrm{C}$ of the TDIC to quantify the role of the unsaturated zone: the example of the Vaucluse karst systems (Southeastern France). Journal of Hydrology, 279 (1-4): 262-274. 
Fairchild I.J., Borsato A., Tooth A.F., Frisia S., Hawkesworth C.J., Huang Y., McDermott F. \& Spiro B., 2000 - Control on trace element ( $\mathrm{Sr}-\mathrm{Mg}$ ) compositions of carbonate cave waters: implications for speleothem climatic records. Chemical Geology, 166: 255-269.

Fairchild I.J. \& McMillan E.A., 2007 - Speleothems as indicators of wet and dry periods. International Journal of Speleology, 36 (2): 69-74.

Fairchild I.J., Smith C.L., Baker A., Fuller L., Spötl C., Mattey D., McDermott F. \& E.I.M.F., 2006 Modification and preservation of environmental signals in speleothems. Earth Science Reviews, 75: 105-153

Ford D.C. \& Williams P.W., 1989 - Karst geomorphology and hydrology. Unwin Hyman, London, $601 \mathrm{pp}$.

Ford D.C. \& Williams P.W., 2007 - Karst Hydrogeology and Geomorphology. Chichester, Wiley. $561 \mathrm{pp}$.

Genty D. \& Deflandre G., 1998 - Drip flow variations under a stalactite of the Père Noël cave (Belgium). Evidence of seasonal variations and air pressure contraints. Journal of Hydrology, 211 (1-4): 208-232.

Groves C., 2007 - Hydrological methods. In: Goldscheider N. \& Drew D. (eds.), Methods in Karst Hydrogeology, Taylor \& Francis, 45-64.

Jeannin J.P., Groves C. \& Häuselmann P., 2007 - Speleological investigations. In: Goldscheider N. \& Drew D. (eds.), Methods in Karst Hydrogeology, Taylor \& Francis, 25-44.

Jennings J.N., 1987 - Karst Geomorphology. Blackwell, Basil.

Kogovsek, J., 1997 - Water tracing tests in the vadose zone. In: Kranjc, A. (Ed.) - Tracer Hydrology 97. Rotterdam, Balkema: 167-72.

Liñán C., Andreo B., Carrasco F. \& Vadillo I., 1999 Hidrodinámica e hidroquímica de las aguas de goteo de la Cueva de Nerja. In: Andreo B., Carrasco F. \& Durán J.J. (Eds.), Contribución del estudio cientifico de las cavidades kársticas al conocimiento geológico, 393402.

Maloszewski P., Stichler W., Zuber A., Rank d., 2002 - Identifing the flow systems in a karstic-fissuredporous aquifer, the Schneeaple, Austria, by modelling of environmental ${ }^{18} \mathrm{O}$ and ${ }^{3} \mathrm{H}$ isotopes. Journal of Hydrology, 256: 48-59.

Mangin A., 1975 - Contributionàl'étude hydrodynamique des aquifères karstiques. Ann. Spéléol., 29(3): 283332, 29(4): 495-601, 30(1): 21-124.

McMillan E., Fairchild I.J., Frisia S., Borsato A., \&McDermott F., 2005 - Annual trace element cycles in calcite aragonite speleothems: evidence of drought in the western Mediterranean 1200-1100 yr BP. Journal of Quaternary Science, 20: 423-433
Mudry J., 1981 - Sur l'origine des gradients des teneurs isotopiques et géochimiques dans les eaux karstiques du Jura (France). Journal of Hydrology, 50: 167178.

Perrin J., Jeannin P.-Y., Zwahlen F., 2003a. - Epikarst storage in a karst aquifer: a conceptual model based on isotopic data, Milandre test site, Switzerland. Journal of Hydrology, 279: 106-124.

Perrin J., Jeannin P.-Y., Zwahlen F., 2003b. Implications of the spatial variability of infiltrationwater chemistry for the investigation of a karst aquifer: a field study at Milandre test site, Swiss Jura. Hydrogeology Journal, 11: 673-686.

Shuster E.T. \& White W.B., 1971 - Seasonal fluctuations in the chemistry of limestone springs: a possible means for characterizing carbonate aquifers. Journal of Hydrology, 14: 93-128.

Smart P.L. \& Friederich H., 1986 - Water movement and storage in the unsaturated zone of a maturely karstified aquifer, Mendip Hills, England. Proceedings of the Conference on Environmental Problems in Karst terrains and their solutions, 57-87. National Water Wells Association, Bowling Green, KY.

Tooth A.F. \& Fairchild I.J., 2003 - Soil and karst aquifer hydrological controls on the geochemical evolution of speleothem-forming drip waters, Crag cave, southwest Ireland. Journal of Hydrology, 273: 51-68.

White W.B., 1988 - Geomorphology and hydrology of karst terrains. Oxford Univ. Press, 464 p.

Williams P.W., 1983 - The role of the subcutaneous zone in karst hydrology. Journal of Hydrology, 61: 45-67.

Williams P.W., 2008 - The role of the epikarst in karst and cave hydrogeology: a review. International Journal of Speleology, 37 (1): 1-10.

Worthington S.R.H., Davies G.J. \& Quinlan J.F., 1992 - Geochemistry of springs in temperate carbonate aquifers: recharge type explain most of the variation. Proc. $5^{\text {th }}$ Conference on Limestone Hydrology and Fissured Media, Neuchatel, Switzerland, 341-347.

Yonge C.J., Ford D.C., Gray J. \& Schwarcz P., 1985 - Stable isotope studies of cave seepage water. Chemical Geology (Isotope Geoscience Section), 58: $97-105$.

Zwahlen F (Ed.), 2004 - Vulnerability and risk mapping for the protection of carbonate (karst) aquifers. Final report of COST Action 620. European Commission, Directorate-General XII Science, Research and Development, Brussels. 297. 